\title{
Badanie odporności na utlenianie mieszanin olejów otrzymanych z regeneracji olejów przepracowanych z olejami naftenowymi
}

\author{
Measurement of oxidation resistance of oil mixtures obtained from regeneration of used \\ oil with naphthenic oils
}

\author{
Małgorzata Smoliło \\ Instytut Katalizy i Fizykochemii Powierzchni im. Jerzego Habera, Polskiej Akademii Nauk w Krakowie
}

\begin{abstract}
STRESZCZENIE: Praca dotyczy wpływu procesu utleniania na właściwości fizykochemiczne olejów smarowych. Przedstawiono otrzymywanie i właściwości olejów naftenowych oraz procesy zachodzące podczas eksploatacji olejów - ze szczególnym uwzględnieniem reakcji utlenienia. Temat jest ciekawy, biorąc pod uwagę postępujący rozwój technologii i motoryzacji oraz wagę regeneracji przepracowanych olejów smarowych. W badaniach zastosowano dwa rodzaje olejów: T22 - olej naftenowy oraz N100 - olej uzyskany z regeneracji olejów przepracowanych. Skład i budowa oleju przepracowanego jest ściśle związana ze stopniem jego zużycia, źródłem pochodzenia poszczególnych składników olejów bazowych, z zaistniałymi przemianami fizykochemicznymi, jak również z ilością zawartych zanieczyszczeń powstałych na skutek zbiórki i magazynowania olejów zużytych. Stopień toksyczności oleju zależy od warunków i czasu eksploatacji oraz od sposobu i warunków zbiórki. Im dłuższy jest czas użytkowania oleju, tym większa jego toksyczność. Badania dotyczą odporności na utlenianie tych olejów oraz ich mieszanin, a także skuteczności działania inhibitorów utleniania w tych olejach. Potwierdzono skuteczność działania zastosowanych inhibitorów. Po dodaniu do badanych olejów, jak również do ich mieszanin antyutleniacza ich odporność na utlenianie zdecydowanie wzrosła. Oleje smarowe poddano badaniu takich właściwości jak: lepkość, zawartość siarki, liczba kwasowa i gęstość. Olej naftenowy charakteryzował się lepszą odpornością na utlenianie niż oleje przepracowane otrzymane w procesie regeneracji. Dodatki inhibitujące proces utleniania skutecznie działały w obu olejach i ich mieszaninach. Dodatek aminowy wykazał się większą skutecznością niż dodatek fenolowy. Na inhibitowanie procesu utleniania wpływ miało stężenie dodawanego antyutleniacza. W przypadków olejów naftenowych antyutleniacz fenolowy był bardziej skuteczny w zakresie wyższych stężeń, a antyutleniacz aminowy w stężeniach niższych. W przypadku olejów z regeneracji inhibitor fenolowy był bardziej skuteczny w stężeniach wyższych, a antyutleniacz aminowy w stężeniach niższych. Zarejestrowano kilkadziesiąt razy mniejszą zawartość siarki w oleju z regeneracji w porównaniu do oleju naftenowego.
\end{abstract}

Słowa kluczowe: oleje smarowe, oleje naftenowe, oleje przepracowane, regeneracja olejów przepracowanych.

ABBSTRACT: This publication concerns the influence of the oxidation process on oil properties. The work contains a description of the properties and production of naphthenic oils and processes related to the exploitation of oils. This topic is really interesting in view of the ongoing development of technology and the automotive industry, and the importance of regeneration of used oils. Two types of oils were used in the tests: T22 - naphthenic oil and N100 - oil obtained from regeneration of used oils. The consistency and structure of used oils are strongly connected to the degree to which it has been used, the original sources of individual basic oil components, physicochemical changes, and also the amount of contaminants. The level of toxicity depends on the environmental conditions, adaption time and on the method and conditions of collection. The longer the oil is used, the more toxic it becomes. The research examined the oxidation resistance of these oils and their mixtures and also the effectiveness of the inhibitors' function in these oils. In this research, the function of inhibitor effectiveness was confirmed. After addition of antioxidant to the examined oils and mixtures, their level of resistance increases. These oils were tested for stickiness, sulphur content, density and acidity. Naphthenic oil was more resistant than the oil obtained from the regeneration process of used oils. Antioxidants are effective in both oils. The addition of an amine antioxidant was more effective than a phenol antioxidant. The concentration of antioxidant had an impact on this process. In case of naphthenic oils, the phenol antioxidant was more effective in a higher concentrations, the amine antioxidant - in lower concentrations. For regenerated oils, the phenol inhibitor was more effective at higher concentrations and the amine antioxidant at lower concentrations. The amount of sulphur in the oil was several tens of times smaller than in naphthenic oil.

Key words: lubricating oils, naphthenic oils, used oils, regeneration of used oils.

Autor do korespondencji: M. Smoliło, e-mail:ncsmolil@cyf-kr.edu.pl

Artykuł nadesłano do Redakcji: 28.01.2020 r. Zatwierdzono do druku: 20.05.2020 r. 


\section{Wprowadzenie}

Oleje smarowe to kompozycje składające się z oleju bazowego i dodatków uszlachetniających, których zawartość może sięgać nawet $30 \%$. Baza olejowa może mieć pochodzenie zarówno mineralne (tzn. gdy powstała na skutek procesów przeróbczych ropy naftowej), jak i syntetyczne (gdy otrzymano ją $z$ reakcji syntezy). Oleje mineralne to mieszanina wysokowrzących węglowodorów nasyconych $i$ aromatycznych $\mathrm{z}$ niewielką zawartością związków heteroorganicznych, zwłaszcza heterocyklicznych (Surygała, 2006). Węglowodory nasycone stanowią bardzo pożądany składnik, a zwłaszcza niskokrzepnące izoparafiny, jak i związki naftenowe (jedno-, dwu- i trójpierścieniowe) zawierające długie podstawniki alkilowe. Zdecydowanie niepożądanymi składnikami olejów są wielopierścieniowe związki naftenowe, które to zmniejszają wskaźnik lepkości olejów i ich odporność na procesy utleniania. Proces ich wydzielenia z destylatów w rafinacji jest trudny, dlatego są one obecne w olejach w niewielkich ilościach. Do pożądanych składników z grupy węglowodorów aromatycznych zalicza się alkilobenzeny, a także dwupierścieniowe związki aromatyczno-naftenowe o długim podstawniku alkilowym. Aromaty jako składniki baz olejowych są pożądane ze względu na ich zdolność do rozpuszczania dodatków i zanieczyszczeń, jednak nie są odporne na utlenianie i charakteryzują się zbyt wysoką lotnością. Alkilobenzeny sa bardzo przydatne przy pracy silników w warunkach niskotemperaturowych. Oleje mineralne otrzymuje się na drodze destylacji próżniowej i z pozostałości po destylacji ropy naftowej. Oleje syntetyczne tworzą związki chemiczne o jednorodnej budowie chemicznej. Zalicza się do nich: polialfaolefiny (PAO), estry, poliestry i poliglikole. Większość syntetycznych olejów bazowych zostaje wytworzona z surowców petrochemicznych (np. ropy naftowej lub gazu ziemnego), które uległy odpowiednim przemianom i wzbogaceniu dodatkami uszlachetniającymi (Totten, 2003). Większość węglowodorów syntetycznych olejów bazowych powstaje z etylenu i innych olefin. Podczas połączenia olejów syntetycznych z bazowymi olejami mineralnymi i dodatkami uszlachetniającymi powstają tzw. oleje półsyntetyczne. Otrzymane oleje bazowe mineralne z ropy naftowej, jak i oleje syntetyczne nie są w stanie dobrze spełniać funkcji wymaganych od współczesnych olejów. Ich klasa i jakość są modyfikowane poprzez wprowadzane dodatki uszlachetniające, których rodzaj i stężenie mają ścisły związek z gatunkiem danego oleju i jego przeznaczeniem. Najczęściej do baz olejowych są wprowadzane tzw. pakiety dodatków poprawiających ich właściwości użytkowe. Ze względu na sposób działania dodatków wyróżnia się:

- dodatki poprawiające właściwości już istniejące - są to np. wiskozatory, depresatory, dodatki obniżające temperaturę płynięcia itp.;
- dodatki, które wprowadzają ze swym składem nowe właściwości - są to np. detergenty i dyspergatory;

- dodatki mające na celu ochronę oleju przed utratą właściwości użytkowych - np. inhibitory utleniania, korozji, rdzy itp. (Michałowska, 1977; Kajdas, 1979; Dudek, 1994).

Współczesny olej smarowy stosowany do prawidłowej pracy silnika stanowi integralny element konstrukcyjny. Oleje smarowe zmniejszają szybkość zużywania się maszyn poprzez skuteczne smarowanie wzajemnie poruszających się elementów. Smarowanie przy zastosowaniu olejów polega na utworzeniu olejowego filmu o odpowiedniej grubości i wytrzymałości w celu zachowania ciągłości i zapobiegania kontaktowaniu się elementów metal-metal. Smarowanie takie określa się mianem hydrodynamicznego, a smarowanie, w wyniku którego dochodzi do kontaktu dwóch elementów trących, to smarowanie graniczne. Oleje powinny spełniać wymagania projektowe narzucane przez konstruktorów silnika, a często nawet są z nim opracowywane równolegle. W komponowaniu oleju smarowego należy uwzględniać zmienne warunki pracy oleju, np. w przypadku olejów do silników samochodowych olej taki winien być odporny na niskie temperatury w okresie zimowym (tzw. zimny start silnika), pracę na biegu jałowym, różne obciążenie, aż do zatrzymania silnika. Olej powinien spełniać wszystkie wyznaczone dla niego funkcje w silniku, m.in. zapobiegać zacieraniu elementów silnika, odprowadzać ciepło, chronić przed korozją, zapewniać szczelność w komorze spalania i utrzymywać jej czystość (PN-81/C-04011). Wraz z rozwojem nowoczesnych technologii olejom są stwarzane bardzo ciężkie i niesprzyjające warunki pracy, takie jak wysoka temperatura i ciśnienie, które znacznie wpływają na tempo jego utlenienia i rozkładu. Oleje silnikowe o dobrych właściwościach eksploatacyjnych powinny obniżać do minimum zużycie powierzchni trących podczas pracy silnika. Właściwość ta jest zależna na przykład od odpowiedniej lepkości i smarności oleju. Oleje powinny także zapewniać łatwe uruchamianie zimnego silnika we wszystkich możliwych warunkach eksploatacji, czemu sprzyja odpowiednia lepkość i temperatura krzepnięcia oleju. Do innych funkcji olejów należy schładzanie silnika oraz uszczelnianie luzów w celu niedopuszczenia spalin do miski olejowej (Podniało, 2002). Ważnym aspektem stosowania olejów smarowych jest także ochrona silnika przed przedwczesnymi procesami korozyjnymi. W wyniku zachodzącego w komorze silnika spalania paliwa powstaje między innymi para wodna, która systematycznie jest odprowadzana w postaci spalin. Jednakże część pary wodnej ulega skropleniu na ściankach cylindrów, w wyniku czego tworzy z gazami spalinowymi, zawierającymi tlenki siarki, środowisko korozyjne. Kwaśne produkty obecne w olejach przyczyniają się również do starzenia się oleju, powodując w efekcie rdzewienie i korozję wszystkich elementów silnika. W celu ograniczenia 
tych niekorzystnych oddziaływań stosowane są dodatki przeciwkorozyjne do oleju oraz dodatki nadające olejowi zdolności neutralizacyjne. Reasumując, olej smarowy jest fundamentalnym elementem silnika i innych urządzeń mechanicznych, a jego funkcje są bardziej złożone niż wyłącznie smarowanie elementów trących (Dudek, 1994; Rudnick, 2013).

\section{Oleje przepracowane - budowa, pochodzenie, właściwości dodatków, wpływ na środowisko i człowieka, regeneracja}

Olejami przepracowanymi, często nazywanymi także olejami zużytymi lub też odpadowymi, nazywa się wszelkie oleje smarowe lub przemysłowe pochodzenia mineralnego, które zgodnie z Ustawą z dnia 14 grudnia 2012 r. o odpadach (Dz.U. z 2019 r. poz. 701 z późn. zm.) nie nadają się do ponownego zastosowania (Żółty, 2014). Oleje przepracowane to nie tylko takie, które stały się niezdatne do użytkowania w wyniku eksploatacji w różnego typu urządzeniach, ale także takie, które straciły swoje właściwości w wyniku nieprawidłowego magazynowania, transportu lub powszechnego procesu starzenia się (Marczak i Majkowska, 2012). Skład i budowa oleju przepracowanego jest ściśle związana z rodzajem zużytego oleju, źródłami pochodzenia poszczególnych składników olejów bazowych, zaistniałymi przemianami fizykochemicznymi, jak również z ilością zawartych zanieczyszczeń powstałych na skutek zbiórki i magazynowania olejów zużytych (Suchecki et al., 2015). Stopień toksyczności oleju zależy od warunków i czasu stosowania oraz od sposobu zbiórki. Im dłuższy jest czas użytkowania (termooksydacji) oleju, tym jego toksyczność jest większa. Stopień toksyczności określa się na podstawie składu chemicznego i działania toksycznego na mikroorganizmy, ssaki oraz ryby (Marczak i Majkowska, 2012). W wyniku długotrwałego utlenienia składników mineralnych oleju bazowego podczas pracy silnika powstają np. laki, żywice i wielopierścieniowe węglowodory aromatyczne (Markiewicz, 2002). Zanieczyszczenia i domieszki w oleju przepracowanym zawierają się w przedziale 20-30\% masowych - zostało to przedstawione szczegółowo w tabeli 1.

Tabela 1. Skład zanieczyszczeń oleju zużytego (Base Oil Handbook, 2011)

Table 1. Composition of used oil impurities (Base Oil Handbook, 2011)

\begin{tabular}{|l|l|}
\hline Woda & do $10 \%$ masowych \\
\hline Niespalone paliwo & do $10 \%$ masowych \\
\hline Sole i tlenki metali & do $0,5 \%$ masowego \\
\hline Produkty zużycia mechanicznego & do $0,5 \%$ masowego \\
\hline Siarka & ok. $1 \%$ masowego \\
\hline
\end{tabular}

Ponadto oleje przepracowane mogą posiadać częściowo zdegradowane dodatki uszlachetniające, sadzę, wielopierścieniowe węglowodory aromatyczne (WWA) i wielopierścieniowe związki aromatyczne (WZA), organiczne związki chloru, wolne kwasy organiczne i mineralne, płyny hamulcowe, dodatki zapobiegające zamarzaniu, rozpuszczalniki, oleje roślinne $\mathrm{i}$ inne podobne ciecze o konsystencji oleistej. Występowanie wody w olejach zużytych stanowi wynik złego zabezpieczenia pojemników, w których jest olej składowany. Węglowodory lekkie, zwykle nieprzekraczające 10\% masowych oleju, pochodzą z niespalonego paliwa. Źródłem występowania metali w olejach przepracowanych są między innymi produkty korozji i zużycia współpracujących powierzchni metalowych, których tarcie jest minimalizowane przez olej smarowy oraz dodatki funkcyjne. Najczęstsze metale pochodzące ze zużycia powierzchni metalowych to: żelazo, chrom, nikiel, glin, miedź, cyna itp. Mogą one być zawieszone w oleju lub wytrącone $\mathrm{w}$ formie osadu. Pierwiastki takie jak np. wapń, magnez czy bar mogą być wprowadzane wraz z popiołowymi detergentami, za to cynk jest podstawowym składnikiem przeciwutleniających dodatków wysokotemperaturowych, które mają na celu poprawę jakości oleju smarowego. Innym źródłem metali może być paliwo, np. ołów wykrywany w śladowych ilościach $\mathrm{w}$ olejach przepracowanych pochodzi z benzyny ołowiowej, która jeszcze jest stosowana w niektórych krajach Europy Wschodniej. W Polsce od 2001 roku stosowanie benzyny etylizowanej jest zakazane, stąd też zawartość ołowiu w przepracowanych olejach z roku na rok się zmniejsza. Obecnie zawartość metali w olejach w krajach europejskich sięga około 0,7\% masowych. Wszelkie dodatki uszlachetniające (np. sulfoniany, ditiofosforany, siarkowane węglowodory itp.) wnoszą do olejów zużytych siarkę (Łuksa, 2010). Inhibitory utleniania, takie jak np. ditiofosforany cynku, czy dodatki przeciwzużyciowe wpływają na zawartość w olejach przepracowanych fosforu. Związki chloropochodne, takie jak chloroparafina lub polichlorowane bifenyle, były często stosowane jako ciecze elektroizolacyjne. Zawartość chloru po eksploatacji oleju może wzrosnąć nawet 20-krotnie. Przeprowadzone badania wskazują, że wzrost chloru może występować na skutek obecności różnych rodzajów chlorowanych węglowodorów, a zwłaszcza substancji stosowanych jako rozpuszczalniki, m.in. 1,1,1-trichloroetanu (około 0,089\% mas.) i perchloroetylenu (około 0,088\% mas.). Chlorowe zanieczyszczenia pojawiają się podczas zbiórki i magazynowania olejów smarowych (Łuksa, 2010). Zawartość WWA zwiększa się wraz z upływem czasu pracy urządzenia. Oleje przepracowane zawierają najczęściej następujące węglowodory aromatyczne: fluoranten (od 0,28\% mas.), piren (do 0,186\% mas.), naftalen (do 0,144\% mas.), benzo[a]antracen (0,073\% mas.). Jakość ropopochodnych płynów eksploatacyjnych ma niezmierny wpływ 
na ich wykorzystanie. Istnieją sposoby na zagospodarowanie olejów przepracowanych. Jednym z nich jest eliminacja $\mathrm{z}$ bazowych produktów naftowych składników niepożądanych poprzez rafinację, odparafinowanie, odasfaltowanie, izomeryzację itp. Innym sposobem jest wzbogacanie składu produktów bazowych w komponenty modyfikujące jedną lub więcej właściwości funkcjonalnych czy eksploatacyjnych (Magiera, 2006). W przypadku braku możliwości regeneracji lub uzdatniania oleju przepracowanego istnieje możliwość utylizacji przepracowanych olejów smarowych w specjalnych urządzeniach z pozyskiwaniem (PN-EN ISO 12185). W rafineriach zebrane oleje przepracowane składowane są w zbiornikach magazynowych, gdzie następuje ich oczyszczanie w procesie dekantacji. Oczyszczony wstępnie olej przepracowany poddawany jest następnie destylacji. Tak zaczyna się rerafinacja, która ma na celu polepszenie własności fizykochemicznych i użytkowych produktów z instalacji frakcjonowania olejów przepracowanych (PN-85/C04066). Proces rerafinacji przebiega w trzech etapach. W pierwszym etapie oczyszczania/destylacji oleju przepracowanego następuje oddzielenie wody, gazoliny i lekkich roztworów. W składzie płynnej fazy znajdują się zwykle kwasy organiczne i składniki często zawierające toksyny, jak np. fenol. Faza skroplonych węglowodorów zawierać może roztwory chlorkowe i wymaga specjalnej obróbki. W drugim etapie regeneracji olejów smarowych następuje eliminacja wysoce stabilnych struktur poprzez użycie różnorodnych technik w zależności od potrzeb rafineryjnych. Ten etap obejmuje też destylację próżniową, dzięki której otrzymuje się dobrą separację pomiędzy produktami destylacji próżniowej a prawie wszystkimi zanieczyszczeniami pozostającymi na dole kolumny próżniowej. Pozostałość, która nadal zawiera olej, może być użyta jako materiał wiążący dla bituminów, spalona lub skierowana do instalacji odasfaltowania, gdzie ilość odzyskanego oleju bright stock jest względnie duża. Na tym etapie występuje też proces odasfaltowania, który pozwala na separację twardej pozostałości, wymagającej rozcieńczenia w celu wypompowania ze spodu kolumny. Osiąga się tutaj maksymalną ilość oleju odasfaltowanego. W ostatnim etapie regeneracji następuje rafinacja oczyszczonych olejów. Przeprowadza się ją w celu usunięcia pozostałych zdyspergowanych i rozpuszczonych dodatkowych zanieczyszczeń oraz odzyskania takich własności oleju bazowego jak: kolor, stabilność barwy, niska zawartość węgla Conradsona, kwasów i liczb podstawowych (PN-EN ISO 20884-2012; Przewoźnik i Grzesik, 2005).

W olejach bazowych pochodzących z przeróbki ropy naftowej poziom WWA jest bardzo niski, za to w olejach zużytych poprzez eksploatację w silnikach o zapłonie iskrowym poziom tych związków może być nawet 1000-krotnie wyższy niż w świeżym oleju. Dodatki uszlachetniające poprawiające własności świeżych olejów smarowych ulegają razem z olejem w czasie eksploatacji istotnym zmianom chemicznym. Proces utleniania, spowalniany i modyfikowany przez inhibitory zawarte w oleju, przebiega równolegle ze zmianami struktury chemicznej dodatków uszlachetniających. Udowodniono toksyczny wpływ na organizmy żywe m.in. fenoli, których zawartość w produktach smarowych mieści się w okolicach 1\% masowego. Do środków średnio toksycznych zalicza się ditiofosforany cynku i pochodne fenoli z zawadą przestrzenną. Żaden $z$ dodatków nie wpływa na pogorszenie procesu oczyszczania ścieków. W wyniku słabej rozpuszczalności w wodzie dodatków olejowych cechuje je mała biodegradowalność.

Dobrą zdolność biodegradacji posiadają polialfaolefiny o stosunkowo niewielkiej lepkości, gdyż zwiększenie lepkości powoduje spadek szybkości rozkładu biologicznego. Dodatki do środków smarowych, oleje bazowe oraz WWA posiadają zdolność biokumulacji w żywych organizmach, a w środowisku są nietrwałe. Toksyczność mieszaniny dodatków jest mniejsza niż toksyczność jej składników (Bryant, 1989). Wydłużenie pracy olejów silnikowych jest równoznaczne ze wzrostem zawartości dodatków, a także ze wzrostem ilości substancji toksycznych w oleju. Wydłużenie czasu pracy na danym oleju wiąże się jednakże ze zmniejszeniem jego całkowitego zużycia, zatem powstaje mniejsza ilość odpadów o zwiększonej zawartości składników niebezpiecznych (Bryant, 1989).

\section{Charakterystyka olejów naftenowych}

Oleje smarowe z uwagi na zróżnicowany skład chemiczny dzieli się na: oleje parafinowe, oleje naftenowe, oleje aromatyczne i oleje mieszane - występujące, gdy żadna z powyższych grup związków nie występuje w ilości dominującej.

Oleje parafinowe charakteryzują się: dużą odpornością na starzenie, wysokimi wartościami punktu anilinowego, dużym wskaźnikiem lepkości, wysoką temperaturą zapłonu i małą gęstością. Oleje naftenowe mają niższą wartość punktu anilinowego, niższą wartość wskaźnika lepkości, a także niższą temperaturę zapłonu i dużą gęstość. Cechy te wynikają z ich składu chemicznego (Kajdas, 1979; Materiały Konsorcjum Olejów Przepracowanych, 2002; Rheinchemie, 2016).

Ropa naftowa, z której produkowane są mineralne oleje smarowe, może być podzielona na dwa podstawowe rodzaje: ropę parafinową i naftenową. Różnice w składzie ropy mogą zależeć od gatunków zwierząt i roślin żyjących w różnych regionach miliony lat temu. Wszystkie rodzaje rop naftowych zawierają mieszaninę różnych węglowodorów, zarówno pierścieniowych z pojedynczymi wiązaniami (związki naftenowe), jak i węglowodorów łańcuchowych i aromatycznych. Źródła rop naftenowych znajdują się w Ameryce 
Południowej i Północnej, na Morzu Północnym, w Europie i Azji. Ropy na Bliskim Wschodzie są przeważnie parafinowe. Duża ilość rop naftenowych wydobywana jest w Wenezueli. Nynas, szwedzki producent specjalistycznych olejów naftenowych, wykorzystuje głównie ropy, z których uzyskuje się oleje naftenowe, posiadające dobre zdolności rozpuszczania i znakomite właściwości niskotemperaturowe. Ponadto oleje Nynas mają doskonały profil środowiskowy, który jest wynikiem zaawansowanych technik rafinacji i hydrorafinacji. Struktury naftenowe to cząsteczki znane też jako cykloalkany o 5, 6 lub 7 atomach węgla - zwykle przeważają cykliczne struktury z 6 atomami węgla. Wykazują one bardzo dobre właściwości niskotemperaturowe i lepsze zdolności solwatacji niż alkany. Oleje naftenowe są praktycznie pozbawione n-alkanów, co oznacza, że mają odpowiednie właściwości niskotemperaturowe, potrzebne do stosowania oleju w niskiej temperaturze. Posiadają lepsze właściwości niskotemperaturowe niż oleje parafinowe. Właściwości niskotemperaturowe określane są na podstawie temperatury krzepnięcia, zależą od lepkości i zawartości komponentów parafinowych oraz od dodatków specjalnych. Z użytkowego punktu widzenia wpływają na zdolność pompowania, rozpylania i smarność oleju w niskich temperaturach. W tabeli 2 zostały przedstawione temperatury płynięcia olejów naftenowych i parafinowych $\mathrm{w}$ temperaturze $40^{\circ} \mathrm{C}$. Temperatura płynięcia olejów naftenowych jest niższa o około $20^{\circ} \mathrm{C}$ niż w przypadku olejów parafinowych o podobnej lepkości (Michałowska, 1977; Marczak i Majkowska, 2012).

Tabela 2. Temperatura płynięcia olejów naftenowych i parafinowych

Table 2. The pour temperature of naphthenic and paraffin oils

\begin{tabular}{|c|c|c|}
\hline $\begin{array}{c}\text { Lepkość } \\
\mathbf{w} \mathbf{4 0}{ }^{\circ} \mathbf{C}\end{array}$ & $\begin{array}{c}\text { Temperatura plynięcia } \\
\text { olejów naftenowych }\end{array}$ & $\begin{array}{c}\text { Temperatura plynięcia } \\
\text { olejów parafinowych }\end{array}$ \\
\hline$[\mathbf{c S t}]$ & {$\left[{ }^{\circ} \mathbf{C}\right]$} & {$\left[{ }^{\circ} \mathbf{C}\right]$} \\
\hline \hline 30 & -39 & -15 \\
\hline 110 & -24 & -3 \\
\hline $400-500$ & -18 & -5 \\
\hline
\end{tabular}

Oleje są podatne na działanie tlenu atmosferycznego, czyli na utlenianie. Oleje produkowane przez Nynas to produkty o wysokiej stabilności oksydacyjnej. Część olejów narażona jest na kondensację wody przy pracy, np. w turbinach parowych. Określenie zdolności do kondensacji wody przez oleje dokonywane jest na podstawie ,parowej metody emulsyjnej”, polegającej na pomiarze czasu, w którym następuje odseparowanie się wody od oleju po wtrysku pary. Jak widać w tabeli 3, wysoko rafinowane oleje naftenowe posiadają lepsze własności separacji wody niż olej parafinowy (Pinko, 2010; Rheinchemie, 2016).
Tabela 3. Zdolność separacji wody

Table 3. Water separation capacity

\begin{tabular}{|c|c|c|}
\cline { 2 - 3 } \multicolumn{1}{c|}{} & Olej parafinowy SN 150 & Olej naftenowy T22 \\
\hline \hline Czas $[\mathrm{s}]$ & 210 & 90 \\
\hline
\end{tabular}

Oleje naftenowe produkowane przez firmę Nynas dzielą się na cztery główne typy:

- NS i T-rafinowane wodorem;

- $\mathrm{S}$ - rafinowane rozpuszczalnikiem i rafinowane wodorem;

- $\mathrm{SR}$ - rafinowane rozpuszczalnikiem;

- T - posiadają wyższą zawartość węglowodorów aromatycznych (Michałowska, 1977).

\section{Czynniki powodujące zużywanie się olejów smarowych}

Na rynku samochodowym pojawiają się pojazdy z silnikami bardziej wysilonymi cieplnie, z mniejszą pojemnością układów smarowania oraz wydłużonymi przebiegami pomiędzy wymianą olejów. Praca takich mechanizmów powiązana jest bezpośrednio ze zwiększonym obciążeniem cieplnym, któremu podlega olej smarowy. W efekcie wymienionych warunków producenci silników wprowadzają nowe technologie poprawiające pracę silnika i efektywność smarowania. Olej smarowy, jako jeden z kluczowych elementów ochraniających silnik podczas pracy, jest narażony na działanie wysokiej temperatury, powstające produkty spalania paliwa mogą rozcieńczać paliwo, przyspieszając proces utleniania. Przyspieszanie zużycia oleju silnikowego może wynikać także z niekorzystnych interakcji pomiędzy składnikami oleju i paliwa. Ponadto na zmiany składu oleju w eksploatacji mają także wpływ układy tzw. następczej obróbki spalin i filtry cząstek stałych, w tym filtry z ciągłą regeneracją. Żywotność oleju w pracującym pojeździe, zwykle określana przez producentów, uzależniana jest od sposobu i warunków eksploatacji maszyny. Wielokrotne rozgrzewanie i chłodzenie silnika przy jazdach na niewielkich odcinkach, nierównomierna praca silnika przy jeździe w korkach ulicznych, uruchamianie silnika w niskich temperaturach, jazda przy dużym obciążeniu bądź na nieprzystosowanych nawierzchniach, eksploatacja silnika przy nadmiernym rozgrzewaniu i gwałtownym jego chłodzeniu i inne warunki - powodują szybszą utratę właściwości użytkowych oleju smarowego i skrócenie czasu jego użytkowania (Rudnick, 2013; Nynas, 2015; Rheinchemie, 2016).

Podczas pracy silnika następuje stopniowe zużywanie się oleju smarowego, co w konsekwencji prowadzi do utraty jego własności smarnych i innych. Podczas rozcieńczenia paliwem oleju smarowego dochodzi do spadku lepkości. Już 10-15\% 
zawartości paliwa powoduje uzyskanie krytycznej zdolności od strony wartości smarowania, mierzona wówczas lepkość kinematyczna w temperaturze $100^{\circ} \mathrm{C}$ sięga zaledwie $6 \mathrm{~mm}^{2} / \mathrm{s}$. Prowadzi to do zerwania ciągłości filmu smarowego, a w konsekwencji do występowania smarowania granicznego lub suchego, które jest niepożądane przy pracy silnika i prowadzi do jego zniszczenia. Procesy destrukcyjne następujące we wnętrzu silnika prowadzą do nasilenia powstawania kwaśnych produktów w degradowanym oleju, co w efekcie skutkuje powstawaniem ognisk korozyjnych. Zmiany we właściwościach eksploatacyjnych mogą być także wynikiem często przedwczesnej degradacji chemicznej, zachodzącej podczas niepożądanych reakcji chemicznych pomiędzy komponentami oleju i dodatkami paliwowymi. Zawartość związków tlenowych i olefinowych w benzynach przyczynia się do tworzenia nierozpuszczalnych szlamów olejowych, a zawartość w olejach napędowych dodatków smarnych powoduje interakcję z dodatkami uszlachetniającymi olejów smarowych, co w efekcie prowadzi do żelowania i zatykania filtrów olejowych. Zmiany właściwości fizykochemicznych oleju smarowego podczas pracy silnika, gromadzenie sadzy, żeli i polimerowych struktur, które zwiększają lepkość oleju, są bardzo niebezpieczne dla pracy silnika. Podczas rozcieńczania oleju smarowego paliwem zawierającym biokomponenty dochodzi do niepożądanych reakcji pomiędzy estrami a olejem silnikowym - szczególnie z modyfikatorem lepkości. Cząstki dodawane do dodatków są zwykle dwubiegunowe - jedna strona jest polarna, a druga strona cząstki niepolarna. Im bardziej polarne są dodatki w niepolarnym oleju bazowym, tym mocniej reagują z polarnymi estrami metylowymi. Estry wpływają także na dodatki przeciwzużyciowe, zmniejszając skuteczność ich działania.

\section{Metodyka badań}

Część doświadczalna niniejszej pracy została przeprowadzona w Instytucie Chemii i Technologii Organicznej Wydziału Inżynierii i Technologii Chemicznej Politechniki Krakowskiej. Badania laboratoryjne polegały na zbadaniu właściwości odporności na utlenianie olejów podstawowych, olejów przepracowanych uzyskanych z regeneracji, olejów naftenowych oraz ich mieszanin $z$ dodatkiem inhibitorów utleniania. Badanie polegało na utlenianiu próbek o masie $30 \mathrm{~g}$ w przystosowanym aparacie do utleniania. Natężenie przepływu powietrza wynosiło $15 \mathrm{l} / \mathrm{h}$, a czas jednego cyklu utleniania to 24 godziny. Próbki ogrzewano do temperatury $130^{\circ} \mathrm{C}$, w której był prowadzony cały proces utleniania. Do próbówek z próbkami wprowadzano miedziane płytki, które pełniły funkcję katalizatora, a cały układ zamknięty był korkiem z odprowadzonymi dwiema rurkami. Jedna z nich służyła do doprowadzania powietrza, a druga do odprowadzania par na zewnątrz układu. Otrzymane próbki olejów poddano podstawowym badaniom w zakresie lepkości i liczby kwasowej, przed i po cyklu przyśpieszonego utleniania, zarówno z dodatkami opóźniającymi ten proces, jak i bez ich udziału. Uzyskane wyniki miały umożliwić ocenę odporności na utlenianie mieszanin olejów otrzymanych z regeneracji i olejów naftenowych oraz skuteczności działania dodatków przeciwutleniających.

\section{Charakterystyka surowców}

Przedmiotem badań były dwa oleje: olej naftenowy T22 i olej bazowy uzyskany z regeneracji olejów przepracowanych N100.

- Olej T22 jest średniej lepkości olejem naftenowym po hydrorafinacji o doskonałej zdolności rozpuszczania i bardzo dobrych właściwościach niskotemperaturowych. Może być stosowany do produkcji cieczy do obróbki metali w wielu różnych operacjach, takich jak: frezowanie, odlewanie, wiercenie, gwintowanie, toczenie, szlifowanie, przeciąganie, nacinanie i docieranie, a także walcowanie. T22 może być również stosowany do wytwarzania niskotemperaturowych smarów i olejów do przekładni automatycznych oraz olejów do prowadnic. Wykazuje doskonałą zdolność rozpuszczania pomimo niskiej zawartości związków poliaromatycznych, pozwala na łatwe rozpuszczenie dodatków. Charakteryzuje się bardzo dobrym powinowactwem do metali, właściwościami chłodzącymi i znakomitymi niskotemperaturowymi. T22 to olej bazowy naftenowy obrabiany wodorem, sklasyfikowane jako olej bazowy grupy V API (Molenda, 1973).

Tabela 4. Właściwości oleju naftenowego T22 (Michałowska, 1977)

Table 4. Properties of naphthenic oil T22 (Michałowska, 1977)

\begin{tabular}{|l|c|}
\hline \multicolumn{1}{|c|}{ Wlaściwości fizykochemiczne } & $\begin{array}{c}\text { Parametry } \\
\text { wymagane }\end{array}$ \\
\hline \hline Gęstość w temp. $15^{\circ} \mathrm{C}\left[\mathrm{kg} / \mathrm{m}^{3}\right]$ & 0,902 \\
\hline Lepkość kinematyczna $\mathrm{w}$ temp. $40^{\circ} \mathrm{C}\left[\mathrm{mm}^{2} / \mathrm{s}\right]$ & 22,3 \\
\hline Lepkość kinematyczna $\mathrm{w}$ temp. $100^{\circ} \mathrm{C}\left[\mathrm{mm}^{2} / \mathrm{s}\right]$ & 3,7 \\
\hline Temperatura zapłonu, $\min .\left[{ }^{\circ} \mathrm{C}\right]$ & 174 \\
\hline Temperatura płynięcia, $\max .\left[{ }^{\circ} \mathrm{C}\right]$ & -45 \\
\hline Barwa, max. & $<0,5$ \\
\hline Pozostałość po koksowaniu, $\max .[\%(\mathrm{~m} / \mathrm{m})]$ & 0,02 \\
\hline Pozostałość po spopieleniu max. $[\%(\mathrm{~m} / \mathrm{m})]$ & 0,005 \\
\hline Zawartość ciał stałych $[\%(\mathrm{~m} / \mathrm{m})]$ & nie zawiera \\
\hline Zawartość wody, max. $[\%(\mathrm{v} / \mathrm{v})]$ & nie zawiera \\
\hline Liczba kwasowa, max. $[\mathrm{mg} \mathrm{KOH} / \mathrm{g}]$ & ok. 0,01 \\
\hline
\end{tabular}


Tabela 5. Właściwości oleju z regeneracji N100 (Molenda, 1973)

Table 5. Oil properties from regeneration N100 (Molenda, 1973)

\begin{tabular}{|l|c|}
\hline \multicolumn{1}{|c|}{ Wlasność } & $\begin{array}{c}\text { Parametry } \\
\text { wymagane }\end{array}$ \\
\hline \hline Gęstość w temp. $15^{\circ} \mathrm{C}\left[\mathrm{kg} / \mathrm{m}^{3}\right]$ & - \\
\hline Lepkość kinematyczna w temp. $40^{\circ} \mathrm{C}\left[\mathrm{mm}^{2} / \mathrm{s}\right]$ & $19,0-25,0$ \\
\hline Lepkość kinematyczna w temp. $100^{\circ} \mathrm{C}\left[\mathrm{mm}^{2} / \mathrm{s}\right]$ & - \\
\hline Temperatura zapłonu, $\min .\left[{ }^{\circ} \mathrm{C}\right]$ & 170 \\
\hline Temperatura płynięcia, max. $\left[{ }^{\circ} \mathrm{C}\right]$ & -12 \\
\hline Barwa, max. & 1 \\
\hline Wskaźnik lepkości, min. & min. 95 \\
\hline Pozostałość po koksowaniu, $\max .[\%(\mathrm{~m} / \mathrm{m})]$ & 0,02 \\
\hline Pozostałość po spopieleniu max. $[\%(\mathrm{~m} / \mathrm{m})]$ & 0,005 \\
\hline Zawartość ciał stałych $[\%(\mathrm{~m} / \mathrm{m})]$ & nie zawiera \\
\hline Zawartość wody, max. $[\%(\mathrm{v} / \mathrm{v})]$ & 0,02 \\
\hline Liczba kwasowa, max. $[\mathrm{mg} \mathrm{KOH} / \mathrm{g}]$ & $<0,05$ \\
\hline
\end{tabular}

- Olej bazowy N100 uzyskano przez hydrorafinację destylatów ropy naftowej i z importowanych olejów przepracowanych. Stosowany jest do produkcji olejów przemysłowych, maszynowych, hydraulicznych, silnikowych i przekładniowych, olejów technologicznych, służących do obróbki skrawaniem, olejów ochronnych i konserwacyjnych (Molenda, 1973).

Właściwości surowców uzyskane z kart charakterystyki zamieszczono w tabelach 4 i 5 .

\section{Charakterystyka inhibitorów utleniania}

\section{- $\quad$ Additin RC 7115}

Bardzo skuteczny fenolowy przeciwutleniacz, stabilny w wysokiej temperaturze, znajduje zastosowanie w: płynach hydraulicznych, olejach turbinowych i sprężarkowych, smarach, olejach przekładniowych, naturalnych i syntetycznych estrach, glikolu polialkilenowym i olejach silnikowych. Właściwości fizykochemiczne inhibitora utleniania Additin RC 7115 przedstawiono w tabeli 6. Wykazuje lepszą skuteczność w stosunku do innych mono- i dimerycznych przeciwutleniaczy fenolowych, co ma związek z jego unikalną strukturą chemiczną. Należy podkreślić, że nie jest to akceptor rodników, ale także ma zdolność rozpuszczania miedzi poprzez tworzenie jej kompleksów, w wyniku czego jest zdolny do usunięcia aktywnego katalizatora ze środowiska reakcji. Ze względu na dużą masę cząsteczkową posiada niewielką tendencję do odparowania, dlatego bardzo dobrze nadaje się do zastosowań wysokotemperaturowych. Jest łatwo rozpuszczalny w olejach mineralnych i syntetycznych olejach bazowych (Metalworking Fluids Handbook, 2006).
Tabela 6. Właściwości inhibitora utleniania Additin RC 7115 (Metalworking Fluids Handbook, 2006)

Table 6. Properties of the oxidation inhibitor Additin RC 7115 (Metalworking Fluids Handbook, 2006)

\begin{tabular}{|l|l|}
\hline Kompozycja & dimeryczny fenol z zawadą przestrzenną \\
\hline Wygląd & sypki, białawy proszek \\
\hline Gęstość $20^{\circ} \mathrm{C}\left[\mathrm{kg} / \mathrm{m}^{3}\right]$ & ok. 1040 \\
\hline Temperatura topnienia $\left[{ }^{\circ} \mathrm{C}\right]$ & ok. 128 \\
\hline Zawartość oleju mineralnego & brak (100\% składnika aktywnego) \\
\hline
\end{tabular}

\section{- $\quad$ Additin RC 7132}

To ciekły, bardzo efektywny antyutleniacz aminowy, łatwy w stosowaniu i powszechnie używany, którego właściwości zostały przedstawione $\mathrm{w}$ tabeli 7 .

Tabela 7. Właściwości inhibitora utleniania Additin RC 7132 (Metalworking Fluids Handbook, 2006)

Table 7. Properties of the oxidation inhibitor Additin RC 7132 (Metalworking Fluids Handbook, 2006)

\begin{tabular}{|l|l|}
\hline Kompozycja & aminowy antyutleniacz \\
\hline Wygląd & czerwonobrązowy, o średniej lepkości \\
\hline Gęstość $20^{\circ} \mathrm{C}\left[\mathrm{kg} / \mathrm{m}^{3}\right]$ & ok. 1090 \\
\hline Temperatura zapłonu $\left[{ }^{\circ} \mathrm{C}\right]$ & ok. 180 \\
\hline Zawartość oleju mineralnego & brak $(100 \%$ składnika aktywnego $)$ \\
\hline Azot $[\%$ mas. $]$ & ok. 5 \\
\hline Lepkość $40^{\circ} \mathrm{C}\left[\mathrm{mm}^{2} / \mathrm{s}\right]$ & ok. 300 \\
\hline
\end{tabular}

Znajduje zastosowanie jako inhibitor utleniania w nośnikach ciepła, olejach do obróbki cieplnej, turbinowych i sprężarkowych, hydraulicznych, przekładniowych, smarach i olejach silnikowych. W porównaniu z innymi aminowymi antyutleniaczami, np. pochodną fenylenodwuaminy, Additin RC 7132 wykazuje lepsze właściwości antyutleniające, a powstające osady nie stanowią rażącego zagrożenia. Gwarantuje doskonałą wydajność w niepolarnych olejach mineralnych i płynach syntetycznych. Ponadto wykazuje bardzo dobrą rozpuszczalność w olejach estrowych. Typowa zawartość tego antyutleniacza w olejach smarowych należy do przedziału od $0,1 \%$ do 0,2\% masowych (Metalworking Fluids Handbook, 2006).

Badania rozpoczęto od podstawowych olejów N100 i T22, a następnie od ich mieszanin w następującym stosunku masowym: $50 \%$ T $22-50 \%$ N100, 25\% T $22-75 \%$ N100 oraz $75 \% \mathrm{~T} 22-25 \% \mathrm{~N} 100$. W kolejnym kroku oleje podstawowe i mieszaniny zostały zmieszane z dodatkiem inhibitorów: - Additin RC 7115 w ilości 0,25\% i 0,5\% masowego; - Additin RC 7132 w ilości 0,25\% i 0,125\% masowego.

Mieszaniny sporządzono w laboratorium, olej i odpowiednie ilości dodatków mieszano przy użyciu mieszadła mechanicznego szklanego przez około 20 minut $\mathrm{w}$ temperaturze nieprzekraczającej $40^{\circ} \mathrm{C}$. 


\section{Omówienie wyników badań}

Oleje przebadano pod kątem podstawowych właściwości fizykochemicznych mających znaczenie w kontekście tematu pracy. Wyniki przedstawiono w tabeli 8 .

Tabela 8. Podstawowe właściwości badanych olejów

Table 8. Basic properties of the tested oils.

\begin{tabular}{|l|c|c|c|}
\hline \multicolumn{1}{|c|}{ Badany parametr } & Jednostka & Olej N100 & Olej T22 \\
\hline \hline Gęstość w $15^{\circ} \mathrm{C}$ & $\mathrm{g} / \mathrm{cm}^{3}$ & 0,850 & 0,894 \\
\hline Lepkość kinematyczna $\mathrm{w} 40^{\circ} \mathrm{C}$ & $\mathrm{mm}^{2} / \mathrm{s}$ & 21,95 & 22,98 \\
\hline Lepkość kinematyczna $\mathrm{w} 100^{\circ} \mathrm{C}$ & $\mathrm{mm}^{2} / \mathrm{s}$ & 4,437 & 3,807 \\
\hline Wskaźnik lepkości & - & 113 & 2,9 \\
\hline Liczba kwasowa & $\mathrm{mg} \mathrm{KOH} / \mathrm{g}$ & 0,004 & 0,023 \\
\hline Zawartość siarki & $\mathrm{mg} / \mathrm{kg}$ & 9,4 & 511,9 \\
\hline
\end{tabular}

Wyznaczone empirycznie wartości mieszczą się w zakresach wartości podawanych przez producenta. Jedynym parametrem odbiegającym od danych producenta jest liczba kwasowa dla oleju T22, niewielka różnica może być spowodowana minimalnym przemiareczkowaniem próbki. Można zatem wysnuć wniosek, że przeprowadzone badania zostały wykonane rzetelnie i prawidłowo. Ciekawość wzbudza zawarta w olejach siarka. W oleju po rerafinacji znajduje się kilkadziesiąt razy mniej siarki niż w przypadku oleju naftenowego. Przygotowane próbki to oleje, mieszanki olejów, oleje z dodatkiem antyutleniaczy oraz mieszaniny olejów z dodatkiem inhibitorów utleniania. Cykl utleniania wykonywano zgodnie $\mathrm{z}$ ustaleniami przez 24 godziny w temperaturze $130^{\circ} \mathrm{C}$. Tabela 9 przedstawia uzyskane wyniki dla olejów podstawowych i ich mieszanin.

Jak widać w tabeli 9, proces utleniania powoduje wzrost lepkości kinematycznej oleju w temperaturze $40^{\circ} \mathrm{C}$ i wzrost jego liczby kwasowej. Mieszaniny olejów bez dodatków antyutleniaczy po cyklu utleniania pogorszyły swe właściwości, co pokazuje duży wzrost liczby kwasowej oraz lepkości. Zauważa się większy wzrost liczby kwasowej badanego oleju N100 otrzymanego z regeneracji olejów przepracowanych. Istotnie zwiększa się również jego lepkość. Zmiany te

Tabela 9. Wyniki utleniania olejów podstawowych i ich mieszanin

Table 9. Oxidation results of basic oils and their mixtures

\begin{tabular}{|c|c|c|c|c|}
\hline \multirow{2}{*}{ Rodzaj mieszaniny } & $\begin{array}{c}\text { Lepkość przed } \\
\text { utlenianiem }\end{array}$ & $\begin{array}{c}\text { LK przed } \\
\text { utlenianiem }\end{array}$ & $\begin{array}{c}\text { Lepkość po } \\
\text { utlenianiu }\end{array}$ & $\begin{array}{c}\text { LK po } \\
\text { utlenianiu }\end{array}$ \\
\hline & {$\left[\mathrm{mm}^{2} / \mathbf{s}\right]$} & [mg KOH/kg] & {$\left[\mathrm{mm}^{2} / \mathbf{s}\right]$} & {$[\mathrm{mg} \mathrm{KOH} / \mathrm{kg}]$} \\
\hline $\mathrm{T} 22$ & 22,98 & 0,022 & 24,22 & 0,393 \\
\hline N100 & 21,95 & 0,004 & 25,19 & 0,656 \\
\hline MIX $1[75 \%$ T22 + 25\% N100] & 21,99 & 0,016 & 24,04 & 0,572 \\
\hline MIX $2[50 \%$ T22 + 50\% N100] & 21,94 & 0,010 & 24,22 & 0,637 \\
\hline MIX $3[25 \%$ T22 + 75\% N100] & 22,05 & 0,009 & 24,63 & 0,749 \\
\hline MIX $4[0,25 \%$ ADDITIN RC $7115+99,75 \%$ N100] & 21,82 & 0,009 & 23,10 & 0,053 \\
\hline MIX $6[0,25 \%$ ADDITIN RC $7115+75 \%$ T $22+25 \%$ N100] & 20,07 & 0,009 & 23,48 & 0,016 \\
\hline MIX 7 [0,25\% ADDITIN RC $7115+(25 \%$ T22 + 72\% N100)] & 21,48 & 0,008 & 22,67 & 0,041 \\
\hline MIX 8 [0,25\%ADDITIN RC $7115+99,75 \%$ T22] & 23,18 & 0,004 & 23,81 & 0,020 \\
\hline MIX $9[0,5 \%$ ADDITIN RC $7115+(50 \%$ T22 + 50\% N100) $]$ & 22,02 & 0,024 & 23,02 & 0,079 \\
\hline MIX $11[0,5 \%$ ADDITIN RC $7115+(25 \%$ T22 + 75\% N100)] & 21,65 & 0,006 & 23,19 & 0,010 \\
\hline MIX 12 [0,5\% ADDITIN RC $7115+99,75 \%$ N100] & 21,94 & 0,020 & 23,81 & 0,022 \\
\hline MIX 16 [0,5\% ADDITIN RC 7115 + 99,5\% T22] & 23,60 & 0,018 & 24,03 & 0,098 \\
\hline MIX 13 [0,25\% Additin RC $7132+(50 \%$ T22 + 50\% N100)] & 21,85 & 0,014 & 22,68 & 0,039 \\
\hline MIX $14[0,25 \%$ Additin RC $7132+(25 \%$ T22 + 75\% N100) $]$ & 22,39 & 0,024 & 22,85 & 0,059 \\
\hline MIX $15[0,25 \%$ Additin RC $7132+(75 \%$ T22 + 25\% N100)] & 21,82 & 0,012 & 22,98 & 0,079 \\
\hline MIX 17 [0,25\% Additin RC $7132+99,75 \%$ N100] & 22,10 & 0,024 & 23,18 & 0,059 \\
\hline MIX 18 [0,25\% Additin RC $7132+99,75 \%$ T22] & 23,12 & 0,020 & 23,53 & 0,039 \\
\hline MIX 19 [0,125\% Additin RC $7132+99,875 \%$ T22] & 22,85 & 0,012 & 24,72 & 0,110 \\
\hline MIX 20 [0,125\% Additin RC $7132+99,875 \%$ N100] & 22,94 & 0,006 & - & - \\
\hline MIX 21 [0,125\% Additin RC $7132+(50 \%$ N100 + 50\% T22)] & 21,65 & 0,006 & - & - \\
\hline MIX $22[\mathbf{0 , 1 2 5 \%}$ Additin RC $7132+(25 \%$ T22 + 75\% N100)] & 21,73 & 0,008 & - & - \\
\hline MIX 23 [0,125\% Additin RC 7132 + (25\% N100 + 75\% T22)] & 22,85 & 0,009 & - & - \\
\hline
\end{tabular}


są bardziej wyraźne niż w przypadku oleju naftenowego T22 występująca podczas utleniania olejów dotyczy ich zabari zaakcentowane także w przypadku mieszanin, zwłaszcza wienia. Po cyklu utleniania zaobserwowano mocno brązowe, mieszaniny, w której składzie znajduje się większa ilość ole- karminowe zabarwienie olejów i ich mieszanin. Zestawienie ju N100. Poza liczbą kwasową i lepkością wyraźna zmiana uzyskanych wyników badań zamieszczono w tabelach 10-14.

Tabela 10. Zestawienie wyników uzyskanych dla oleju naftenowego T22

Table 10. Summary of results obtained for naphthenic oil T22

\begin{tabular}{|c|c|c|c|c|c|}
\hline \multicolumn{2}{|c|}{ Rodzaj antyutleniacza } & $\begin{array}{c}\text { Lepkość } \\
\text { przed utlenianiem }\end{array}$ & $\begin{array}{c}\text { LK } \\
\text { przed utlenianiem }\end{array}$ & $\begin{array}{c}\text { Lepkość } \\
\text { po utlenianiu }\end{array}$ & $\begin{array}{c}\text { LK } \\
\text { po utlenianiu }\end{array}$ \\
\hline Fenolowy RC 7115 & Aminowy RC 7132 & {$[\mathbf{m g ~ K O H / k g ]}$} & 0,022 & 24,22 & 0,393 \\
\hline$[$ m masowy] & {$[\%$ masowy] } & {$\left[\mathbf{m m}^{2} / \mathbf{s}\right]$} & 0,004 & 23,80 & 0,020 \\
\hline \hline- & - & 22,98 & 0,018 & 24,02 & 0,098 \\
\hline 0,25 & - & 23,18 & 0,012 & 24,72 & 0,110 \\
\hline 0,50 & 0,125 & 23,59 & 0,012 & 23,53 & 0,039 \\
\hline- & 0,250 & 22,85 & & & \\
\hline
\end{tabular}

Tabela 11. Zestawienie wyników uzyskanych dla oleju z regeneracji N100

Table 11. Summary of results obtained for oil from regeneration N100

\begin{tabular}{|c|c|c|c|c|c|}
\hline \multicolumn{2}{|c|}{ Rodzaj antyutleniacza } & \multirow{2}{*}{$\begin{array}{c}\text { Lepkość } \\
\text { przed utlenianiem }\end{array}$} & \multirow{2}{*}{$\begin{array}{c}\text { LK } \\
\text { przed utlenianiem }\end{array}$} & \multirow{2}{*}{$\begin{array}{c}\text { Lepkość } \\
\text { po utlenianiu }\end{array}$} & \multirow{2}{*}{$\begin{array}{c}\text { LK } \\
\text { po utlenianiu }\end{array}$} \\
\hline Fenolowy RC 7115 & Aminowy RC 7132 & & & & \\
\hline [\% masowy] & [\% masowy] & {$\left[\mathrm{mm}^{2} / \mathrm{s}\right]$} & [mg KOH/kg] & {$\left[\mathrm{mm}^{2} / \mathbf{s}\right]$} & [mg KOH/kg] \\
\hline- & - & 21,95 & 0,004 & 25,19 & 0,656 \\
\hline 0,25 & - & 21,82 & 0,009 & 23,10 & 0,054 \\
\hline 0,50 & - & 21,94 & 0,019 & 23,80 & 0,022 \\
\hline- & 0,125 & 21,65 & 0,010 & 23,35 & 0,034 \\
\hline- & 0,250 & 22,10 & 0,024 & 23,18 & 0,059 \\
\hline
\end{tabular}

Tabela 12. Zestawienie wyników uzyskanych dla mieszanin olejów T22 i N100 (25:75)

Table 12. Summary of results obtained for mixtures of T22 and N100 oils (25:75)

\begin{tabular}{|c|c|c|c|c|c|}
\hline \multicolumn{2}{|c|}{ Rodzaj antyutleniacza } & \multirow{2}{*}{$\begin{array}{c}\text { Lepkość } \\
\text { przed utlenianiem }\end{array}$} & \multirow{2}{*}{$\frac{\text { LK }}{\text { przed utlenianiem }}$} & \multirow{2}{*}{$\begin{array}{c}\text { Lepkość } \\
\text { po utlenianiu }\end{array}$} & \multirow{2}{*}{$\begin{array}{c}\text { LK } \\
\text { po utlenianiu }\end{array}$} \\
\hline Fenolowy RC 7115 & Aminowy RC 7132 & & & & \\
\hline$[\%$ masowy $]$ & {$[\%$ masowy $]$} & {$\left[\mathrm{mm}^{2} / \mathrm{s}\right]$} & [mg KOH/kg] & {$\left[\mathrm{mm}^{2} / \mathrm{s}\right]$} & {$[\mathrm{mg} \mathrm{KOH} / \mathrm{kg}]$} \\
\hline - & - & 22,050 & 0,009 & 24,63 & 0,749 \\
\hline 0,25 & - & 21,480 & 0,008 & 22,67 & 0,041 \\
\hline 0,50 & - & 21,650 & 0,006 & 23,19 & 0,010 \\
\hline- & 0,125 & 21,735 & 0,008 & 22,94 & 0,020 \\
\hline- & 0,250 & 22,390 & 0,024 & 22,85 & 0,059 \\
\hline
\end{tabular}

Tabela 13. Zestawienie wyników uzyskanych dla mieszanin olejów T22 i N100 (50:50)

Table 13. Summary of results obtained for mixtures of T22 and N100 oils (50:50)

\begin{tabular}{|c|c|c|c|c|c|}
\hline \multicolumn{2}{|c|}{ Rodzaj antyutleniacza } & \multirow{2}{*}{$\begin{array}{c}\text { Lepkość } \\
\text { przed utlenianiem }\end{array}$} & \multirow{2}{*}{$\begin{array}{c}\text { LK } \\
\text { przed utlenianiem }\end{array}$} & \multirow{2}{*}{$\begin{array}{c}\text { Lepkość } \\
\text { po utlenianiu }\end{array}$} & \multirow{2}{*}{$\begin{array}{c}\text { LK } \\
\text { po utlenianiu }\end{array}$} \\
\hline Fenolowy RC 7115 & Aminowy RC 7132 & & & & \\
\hline$[\%$ masowy $]$ & [\% masowy] & {$\left[\mathrm{mm}^{2} / \mathrm{s}\right]$} & [mg KOH/kg] & {$\left[\mathrm{mm}^{2} / \mathrm{s}\right]$} & [mg KOH/kg] \\
\hline- & - & 21,94 & 0,010 & 24,22 & 0,637 \\
\hline 0,25 & - & 22,02 & 0,014 & 23,02 & 0,039 \\
\hline 0,50 & - & 22,02 & 0,024 & 23,02 & 0,079 \\
\hline- & 0,125 & 21,65 & 0,006 & 23,18 & 0,040 \\
\hline- & 0,250 & 21,85 & 0,013 & 22,67 & 0,039 \\
\hline
\end{tabular}


Tabela 14. Zestawienie wyników uzyskanych dla mieszanin olejów T22 i N100 (75:25)

Table 14. Summary of results obtained for mixtures of T22 and N100 oils (75:25)

\begin{tabular}{|c|c|c|c|c|c|}
\hline \multicolumn{2}{|c|}{ Rodzaj antyutleniacza } & \multirow{2}{*}{$\begin{array}{c}\text { Lepkość } \\
\text { przed utlenianiem }\end{array}$} & \multirow{2}{*}{$\begin{array}{c}\text { LK } \\
\text { przed utlenianiem }\end{array}$} & \multirow{2}{*}{$\begin{array}{c}\text { Lepkość } \\
\text { po utlenianiu }\end{array}$} & \multirow{2}{*}{$\begin{array}{c}\text { LK } \\
\text { po utlenianiu }\end{array}$} \\
\hline Fenolowy RC 7115 & Aminowy RC 7132 & & & & \\
\hline [\% masowy] & [\% masowy] & {$\left[\mathrm{mm}^{2} / \mathrm{s}\right]$} & [mg KOH/kg] & {$\left[\mathrm{mm}^{2} / \mathrm{s}\right]$} & [mg KOH/kg] \\
\hline- & - & 22,05 & 0,009 & 24,63 & 0,749 \\
\hline 0,25 & - & 20,07 & 0,010 & 23,48 & 0,016 \\
\hline 0,50 & - & 22,63 & 0,016 & 23,53 & 0,020 \\
\hline- & 0,125 & 22,85 & 0,009 & 24,43 & 0,064 \\
\hline- & 0,250 & 21,82 & 0,012 & 22,98 & 0,079 \\
\hline
\end{tabular}

Zauważono, że po dodaniu do badanych olejów, jak również do ich mieszanin antyutleniacza fenolowego - Additin RC 7115 ich odporność na utlenianie zdecydowanie wzrosła. Skuteczność działania antyutleniacza była widoczna zarówno z małego wzrostu lepkości i liczby kwasowej, jak i niewielkiej zmiany zabarwienia oleju. Inhibitory utleniania z punktu widzenia mechanizmu ich działania przerywają zachodzące reakcje polimeryzacji. Działanie ich polega na zakończeniu łańcuchów reakcji, dlatego bardzo mała ilość inhibitora może powodować ograniczenie stopnia utleniania (PN-EN ISO 20884-2012). Po zwiększeniu stężenia inhibitora fenolowego w mieszaninach z przewagą oleju naftenowego widać wyraźny wzrost liczby kwasowej oraz lepkości. W przypadku próbek $\mathrm{z}$ olejem $\mathrm{z}$ regeneracji lub z jego przewagą obserwowano po zwiększeniu stężenia inhibitora fenolowego mniejszy wzrost liczby kwasowej w porównaniu z mieszaninami o niższym stężeniu inhibitora. Jest to zależność odwrotna niż w przypadku próbek z olejem naftenowym, w którym to zwiększenie stężenia inhibitora fenolowego powodowało zwiększenie liczby kwasowej i lepkości kinematycznej. W mieszaninach z przewagą oleju naftenowego liczba kwasowa podczas dodawania inhibitora fenolowego nieznacznie wzrosła ze wzrostem stężenia antyutleniacza. W mieszaninach z przewagą oleju z regeneracji wraz ze wzrastającym stężeniem antyutleniacza fenolowego zmniejsza się wzrost liczby kwasowej w porównaniu z mieszaninami z przewagą oleju naftenowego. W utlenianych próbkach $\mathrm{z}$ dodatkiem inhibitora aminowego - Additin RC 7132 - liczby kwasowe i lepkości wzrosły, jednak w porównaniu do próbek bez antyutleniacza były to wartości niewielkie. Początkowa porcja ( $0,25 \%$ masowego) antyutleniacza okazała się na tyle skuteczna, że wzrost liczby kwasowej był rzędu setnych mg KOH/kg oleju; podobnie działo się w przypadku lepkości, której wzrost także był niewielki. Wraz ze zmniejszaniem stężenia inhibitora aminowego zmniejszała się liczba kwasowa utlenianych mieszanin olejów z przewagą oleju z regeneracji. W przypadku olejów naftenowych podczas zmniejszania stężenia inhibitora obserwowano zwiększanie się liczby kwasowej oraz lepkości. W mieszaninach z przewagą oleju z regeneracji wraz ze zmniejszającym się stężeniem antyutleniacza aminowego następował niewielki wzrost liczby kwasowej i lepkości kinematycznej, w przeciwieństwie do mieszanin z przewagą oleju naftenowego. Niskie stężenie inhibitora aminowego lepiej inhibitowało proces utleniania w mieszaninach z przewagą oleju z regeneracji. Wyższe stężenie antyutleniacza aminowego w przypadku olejów naftenowych wyraźniej opóźniało ich zużycie.

\section{Wnioski}

Na podstawie przeprowadzonych badań i przeglądu literaturowego wysunięto następujące wnioski:

- olej naftenowy wykazywał lepszą odporność na utlenianie niż olej otrzymany w procesie regeneracji olejów przepracowanych;

- dodatki inhibitujące proces utleniania skutecznie działały w obu olejach i ich mieszaninach. Dodatek aminowy wykazał się większą skutecznością niż dodatek fenolowy;

- na inhibitowanie procesu utleniania wpływ miało stężenie dodawanego antyutleniacza:

- w przypadków olejów naftenowych antyutleniacz fenolowy był bardziej skuteczny w mniejszych stężeniach, a antyutleniacz aminowy w stężeniach wyższych,

- w przypadku olejów z regeneracji inhibitor fenolowy był bardziej skuteczny w stężeniach wyższych, a antyutleniacz aminowy w stężeniach niższych;

- zawartość siarki w oleju z regeneracji była kilkadziesiąt razy mniejsza niż w oleju naftenowym.

Artykuł powstał w ramach realizacji pracy inżynierskiej pt.: Badanie odporności na utlenianie mieszanin olejów otrzymanych $z$ regeneracji olejów przepracowanych z olejami naftenowymi - powstałej pod kierunkiem dr. inż. Mieczysława Chmury na Wydziale Inżynierii i Technologii Chemicznej Politechniki Krakowskiej, styczeń 2016 roku. 


\section{Literatura}

Base Oil Handbook, 2011. Copyright Nynas AB. Communications Department in Sweden. <https://www.nynas.com/pl/product-areas/ base-oils/> (dostęp: 10.02.2016).

Bryant C., 1989. Slick new oil re-refining process. Resource Recycling: 36-37.

Dudek A., 1994. Oleje smarowe Rafinerii Gdańskiej S.A. Część I. Oficyna Wydawnicza „Kamet”, Gdańsk.

Kajdas C., 1979. Chemia i Fizykochemia ropy. WNP, Warszawa.

Łuksa I., 2010. Energetyczne wykorzystywanie olejów przepracowanych w urządzeniach małej energetyki. <http://cleanburn. com.pl/Artykuly/En_wyk_olejow_przepr_w_urz_malej_energ. pdf> (dostęp: 06.04.2020).

Magiera J., 2006. Rerafinacja olejów przepracowanych. WNT, Warszawa.

Marczak M., Majkowska K., 2012. Dodatki do paliw (polepszanie eksploatacyjnych właściwości paliw i olejów). $<$ https://prezi.com/e8eqftwh-zlu/dodatki-do-paliw> (dostęp: 28.12.2015).

Markiewicz M., 2002. Ekologiczne i techniczne aspekty regeneracji olejów przepracowanych. Rozprawa doktorska, Wydziat Inżynierii Środowiska Politechniki Krakowskiej.

Materiały Konsorcjum Olejów Przepracowanych - Organizacja Odzysku S.A. z Konferencji Naukowo-Technicznej „Prawnoorganizacyjne uwarunkowania działalności organizacji odzysku 2002", Warszawa.

Metalworking Fluids Handbook, 2006. Copyright Nynas Naphthenics, Communications Department. Sweden.

Michałowska J., 1977. Paliwa oleje smary. Wydawnictwa Komunikacji i Łaczności, Warszawa

Molenda J., 1973. Technologia chemiczna. Wydanie 2. Państwowe Wydawnictwo Szkolnictwa Zawodowego, Warszawa.

Nynas - oficjalna strona internetowa firmy w Szwecji. <http://www. nynas.com> (dostęp: 27.12.2015).

Pinko J., 2010. Wykorzystanie spektrofotometrii w podczerwieni do oznaczania inhibitora utleniania oraz produktów starzenia w olejach turbinowych uszlachetnionych (TU). Tribologia, 5: 165-172.

Podniało A., 2002. Paliwa, oleje i smary w eksploatacji. WNT, Warszawa.

Przewoźnik D., Grzesik K., 2005. System gospodarowania olejami odpadowymi na terenie województwa podkarpackiego. Inżynieria środowiska, 10(2): 174-184.
Rheinchemie - oficjalna strona internetowa firmy. $<$ http://www.rheinchemie.com/lubricant-additives-en?lang=en $>$ (dostęp: 4.01.2016).

Rudnick L.R., 2013. Synthetics, Mineral Oils, and Bio-Based Lubricants Chemistry and Technology. CRC Press Taylor \& Francis Group: $367-372$.

Suchecki A., Śledź J., Brodzik K., 2015. Zmiana parametrów oleju silnikowego w trakcie próby trwałościowej na hamowni silnikowej. Prace Naukowe Instytutu Nafty i Gazu - Państwowego Instytutu Badawczego, 201: 52-67.

Surygała J. (red.), 2006. Vademecum rafinera - Ropa naftowa właściwości przetwarzanie produkty. WNT, Warszawa.

Totten G.E., 2003. Fuels and Lubricants Handbook: Technology, Properties, Performance and Testing. ASTM Manual series: MNL37WCD, USA: 187-797.

Żółty M., 2014. Ocena korelacji stopnia wyczerpywania inhibitora utleniania typu fenolowego w bezcynkowych olejach turbinowych wyznaczonego metodami IR i RULER. Nafta-Gaz, 12: 961-963.

\section{Akty prawne i normatywne}

PN-81/C-04011 Przetwory naftowe. Oznaczanie lepkości kinematycznej i obliczanie lepkości dynamicznej.

PN-85/C-04066 Przetwory naftowe. Oznaczanie liczby kwasowej i zasadowej oraz kwasowości metodą miareczkowania wobec wskaźników.

PN-EN ISO 12185 Ropa naftowa i ciekłe lub stałe przeroby naftowe - Oznaczanie gęstości lub gęstości względnej.

PN-EN ISO 20884-2012 Przetwory naftowe. Oznaczanie zawartości siarki w paliwach do pojazdów samochodowych. Rentgenowska spektrometria fluorescencyjna $\mathrm{z}$ dyspersją fal.

Ustawa z dnia 14 grudnia 2012 r. o odpadach (Dz.U. z 2019 r., poz. 701 z późn. zm.).

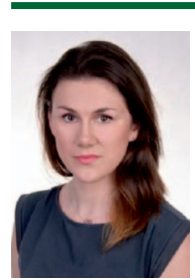

Mgr inż. Małgorzata SMOLIŁO

Doktorantka w Instytucie Katalizy i Fizykochemii Powierzchni im. Jerzego Habera PAN w Krakowie ul. Niezapominajek 8

30-239 Kraków

E-mail:ncsmolil@cyf-kr.edu.pl 